\title{
Do texto e do contexto
}

\section{Encenar hoje $O$ fim de António Patrício}

\section{Christine Zurbach}

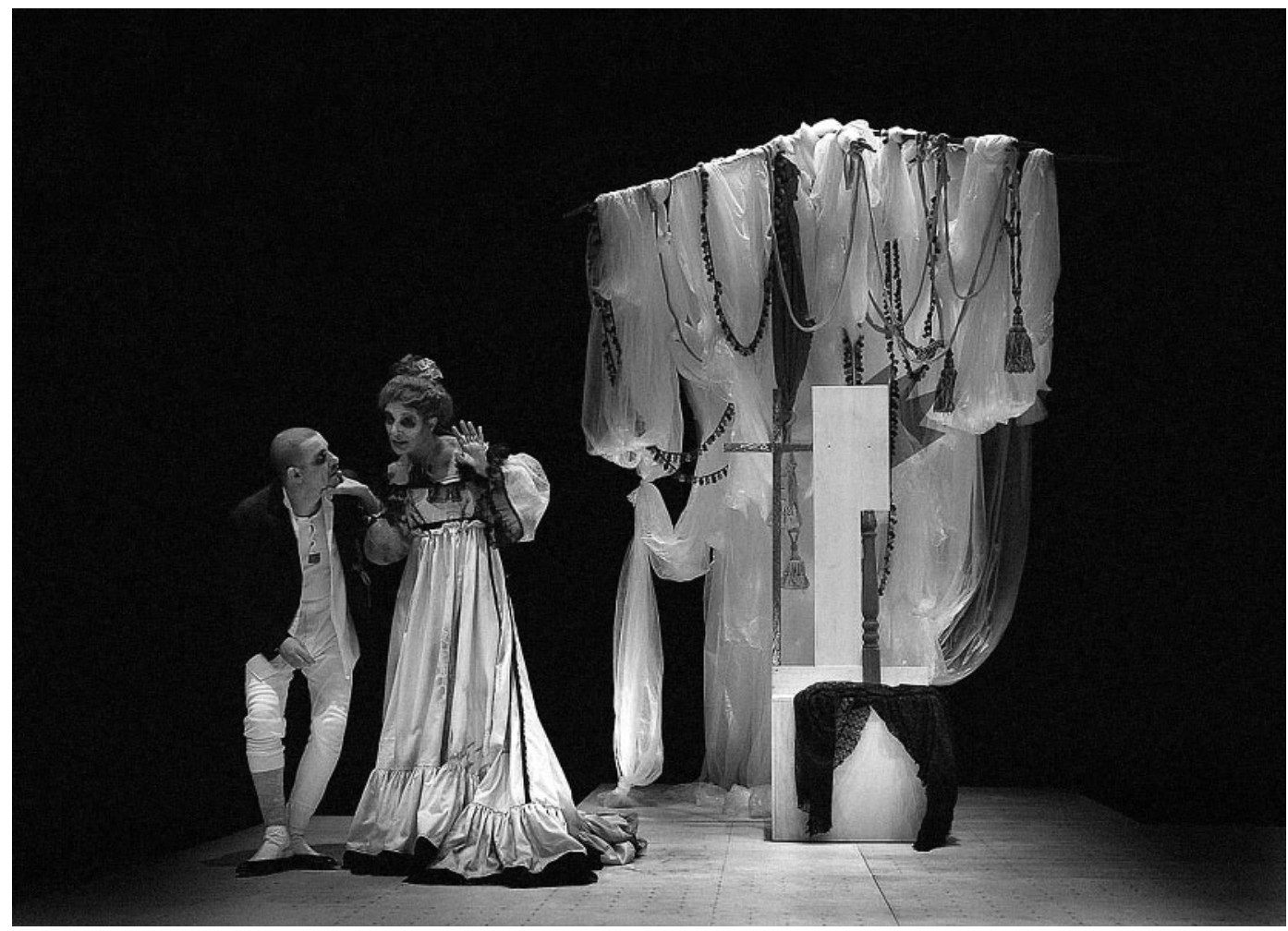

Titulo: $O$ fim (1909). Autor:António Patricio. Versão dramatúrgica:Armando Nascimento Rosa e Victor Zambujo. Encenação:Victor Zambujo. Orgânica sonora: David Martins. Cenografia:Acácio Carvalho. Figurinos: Manuela Bronze. Desenho de Luz: António Rebocho. Interpretação: Álvaro Corte-Real, Jorge Baião, Maria Marrafa, Rui Nuno, Rosário Gonzaga. Produção: CENDREV. Local e data de estreia: Teatro Garcia de Resende, Évora, 8 de Janeiro de 2010.

Para um espectador eborense atento à programação do CENDREV, a escolha de António Patrício não surpreenderá muito. Integra-se numa estratégia assumida de companhia de repertório, pautada por orientações que tendem mais recentemente a privilegiar a dramaturgia de autores portugueses: recorda-se o clássico Gil Vicente em 2007, com o Auto da festa integrado na continuação do programa Painel Vicente iniciado em 1978 com 0 velho da horta, por Mário Barradas, fundador do projecto de teatro em Évora, falecido em finais de 2009; as novas dramaturgias nacionais como o teatro de Nascimento Rosa, com várias peças estreadas em Évora, sendo a última Antigona gelada em 2009, de Abel Neves com Além as estrelas são a nossa casa, de Miguel Real com a peça Memórias de Branca Dias, monólogo que contou com a sensibilidade e maturidade da actriz Rosário Gonzaga, e do dramaturgo
Norberto Ávila, que festejou com o CENDREV na temporada de 2009 cinquenta anos de carreira dramática com a estreia da peça 0 rosto levantado. Mas, quando no ano do centenário da implantação da República, a obra mais emblemática de António Patrício consta das opções de programação de 2010, a essa dedicação declarada à dramaturgia nacional acrescenta-se uma outra valência: a do comprometimento do CENDREV com um sentido social e cultural da prática do teatro no qual o espectador se encontra inserido enquanto cidadão e observador / participante da História.

É, de resto, exemplar a história da recepção cénica de 0 fim: publicada em 1909, a peça parece anunciar a queda do regime monárquico que terá lugar no ano seguinte $\mathrm{e}_{\text {, }}$ quando finalmente é estreada na Casa da Comédia numa encenação de Jorge Listopad em 1971, Portugal está perto 
10 colóquio teve lugar no Salão Nobre do Teatro Garcia de Resende em Évora no dia 09 de Janeiro de 2010. Foi moderado por Armando Nascimento Rosa e Rui Pina Coelho, e contou com a presença dos encenadores Jorge Listopad, responsável pela descoberta da obra para

a cena, na Casa da

Comédia, 1971,

Rui Madeira, que encenou

o texto com a Companhia de Teatro de Braga em 1986 e 1993, Paulo Lages, autor do libreto 0 fimÓpera intima, encenado no Centro Cultural de Cascais em 2004, e Nuno Nunes que trabalhou 0 texto no âmbito da sua formação na Escola Superior de Teatro e Cinema. de concluir um processo decisivo de mudanças políticas com a queda do regime salazarista no 25 de Abril. Para os encenadores convidados a participarem no colóquio "O fim, de António Patrício, 100 anos depois" promovido pelo CENDREV e durante o qual foram evocadas outras encenações entre 1971 e $2010^{1}$, tal articulação entre a fábula da peça e o contexto da sua encenação surgiu de forma quase sistemática, dando conta da atenção que o teatro, mundo da ficção e do imaginário, pode dar ao entendimento da História, dando sentido ao tempo colectivo.

0 colóquio confirmou que, aliado a esse reconhecimento, o discurso em torno da recepção cénica da peça refere de forma reiterada um interessante vínculo da fábula com circunstâncias externas da ficção que tornam pertinente a sua inclusão no repertório vivo do teatro. No programa do espectáculo do CENDREV, é referida essa relação entre a acção narrada nessa obra de António Patrício e a realidade dos factos históricos que pontuam a História de Portugal, considerando-o, por isso, um texto "premonitório (...), que pressente as transformações sociais, politicas e culturais que varreram o século XX".

Assim, se, para o espectador, a sua escolha para a temporada de 2010 permite antecipar opções de leitura cuja tónica será focalizada nas questões de natureza ideológica e nas respectivas dificuldades de interpretação que hoje se levantam, na encenação de Vitor Zambujo, tal abordagem dramatúrgica não ignorou a dimensão artística e estética do texto. E o espectador culto, também ele, conhece a dramaturgia de António Patrício, autor cujo valor hoje é o de um "clássico" da modernidade literária e teatral, e terá lido 0 fim, drama cuja densidade poética é unânime e merecidamente referida e elogiada pelos conhecedores. Aliás, no colóquio já referido aqui, os criadores convidados pelo CENDREV para evocar o seu trabalho sobre a peça concordaram no reconhecimento do desafio inesgotável que a peça representa para os seus intérpretes enquanto obra de viragem, de ruptura, e de esbatimento de fronteiras. Sem dúvida profundamente original relativamente à escrita dramática portuguesa da época, O fimé visto como precursor das inovações artísticas que viriam a surgir mais tarde como o expressionismo, o teatro dito do absurdo, ou ainda o teatro épico.

Nas escolhas iniciais do CENDREV, a peça é tratada como um (quase) monumento textual, "um grande texto de um grande autor português", nas palavras do encenador. A encenação parte de um dado prévio de natureza estruturante: o texto foi objecto de transformações importantes que, como a supressão de personagens e de réplicas, ou a sua redistribuição, tornaram mais proeminentes as figuras centrais do Paço e do mundo exterior: por um lado, a Rainha, o Duque e a Aia, com a passagem do Ministro, e por outro, o Desconhecido, vindo da rua em ebulição. Com o apoio do dramaturgo Nascimento Rosa - que contribuiu para a elaboração da versão eborense do texto - o encenador optou por valorizar no seu trabalho de direcção de actores a beleza de uma escrita que junta nos diálogos a prosa e o verso, realçando desse modo a dimensão insólita que emana da imagem rítmica e sonora das réplicas da Rainha, cujo papel é interpretado por Rosário Gonzaga. Uma outra nota característica de tal opção consiste no tratamento dado ao texto didascálico, enunciado em cena, em jeito de citação da linguagem estético-simbolista que envolve a peça, por uma personagem criada para o efeito - o próprio António Patrício - o que causa um efeito de estranheza, em ruptura com o onirismo do conjunto.

0 espectáculo desenrola-se na zona do palco do Teatro Garcia de Resende, lugar privilegiado para enquadrar o ritual teatralizado da representação, cujo cerimonial 


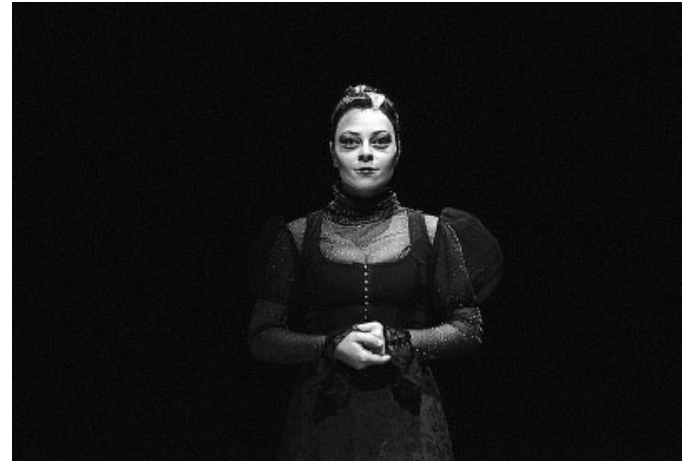

começa pela chegada do espectador ao seu lugar na bancada montada em frente do estrado que representará o palácio, num ambiente algo intimista criado para um público em número restrito, simultaneamente próximo e distante da actuação dos actores. Assim torna-se de imediato claro assim que o discurso que estrutura as opções do encenador nasce na cenografia criada por Acácio de Carvalho, com um dispositivo cénico distribuido entre dois planos. 0 primeiro consiste num palco rectangular, com contornos nítidos e ligeiramente elevado, onde aparecem as figuras. Constitui o espaço da acção, único e comum aos dois actos, mas cuja transformação e degradação seguem o desenvolvimento do enredo: 0 interior do palácio na sala de recepção nos Quadros Primeiro e Segundo, e um espaço circundante no qual actua António Patrício, a personagem acrescentada à distribuição original, que aparece na abertura do espectáculo, mas ainda fora da ficção narrada, e que volta no início do segundo quadro. É o dramaturgo a quem incumbe a tarefa da apresentação - verbalizada em cena - do espaço inventado por ele próprio e descrito nos pormenores das extensas didascálias. A opção de Acácio de Carvalho para a restante cenografia aposta na centralidade de uma construção, um dispositivo cénico reduzido ao mínimo: vertical e abstracto, meio esfarrapado, evoca o simulacro de um trono-altar com um dossel, que funciona como elemento fixo em torno do qual se desenrola o bailado mecânico da Aia, o percurso geométrico do Duque, ser disforme em ceroulas brancas, e da Rainha em devaneios sonhados. Único elemento construído, o trono está no meio de um palco de madeira com furos que deixam pontualmente passar focos de luz ou fumos brancos, que compõem a atmosfera irreal da peça.

É nos limites desse território marcadamente teatral que o discurso da encenação encontra globalmente a sua

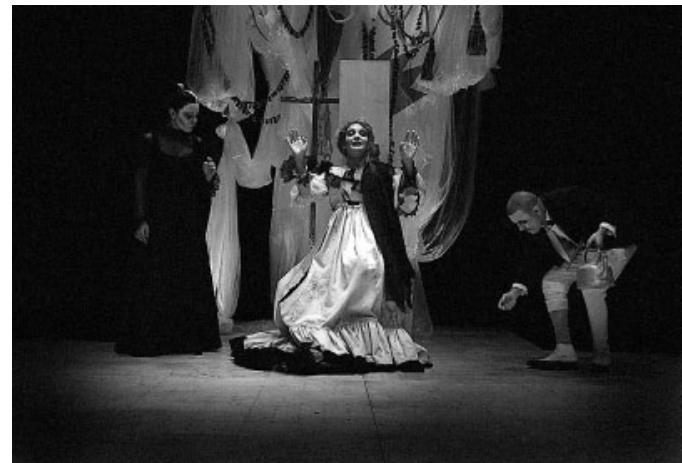

O fim,

de António Patricio,

enc. Victor Zambujo, CENDREV, 2010 (< Maria Marrafa; $>$ Maria Marrafa, Rosário Gonzaga, e Jorge Baião), fot. Paulo Nuno Silva.

materialização, articulando interpretação, cenografia e figurinos, música e luzes numa combinatória que, em termos estéticos e funcionais, privilegia uma linguagem não-realista, simbólica ou simbolista, também reflectida na estilização e na contenção do trabalho gestual dos actores, bem patente na pose algo hierática e nos movimentos sóbrios da personagem da Aia interpretada pela actriz Maria Marrafa. 0 guarda-roupa da autoria de Manuela Bronze foi concebido como "expressão de uma certa estridência na distorção, subtil, dos paradigmas da verosimilhança social e hierárquica", em particular nos três habitantes do Paço, universo do sonho e da ilusão em véspera de uma festa de aniversário que não poderá ter lugar. A imagem criada pela composição plástica das roupas é conotada com um gosto que mescla apontamentos de moda finissecular, ou já fora do tempo, com texturas que reenviam para o requinte das vestes de festas ou de cerimónias, mas numa corte moribunda. A maquilhagem é concebida como uma máscara fúnebre, que sublinha e exagera o contraste entre a palidez dos rostos exangues e o negro dos olhos. No Duque, interpretado por Jorge Baião, o corpo já é apenas o de um boneco articulado cuja mecânica tosca se torna tragicómica na sua tentativa de salvar as aparências ao serviço da Rainha.

No programa e numa carta apócrifa de António Patrício endereçada a Manuel Teixeira-Gomes, Armando Nascimento Rosa recupera e cita a expressão usada pelo penúltimo presidente da Primeira República e autor da tragicomédia Sabina Freire para qualificar a peça: uma "louca rajada shakespeariana". É essa a aposta da leitura de 0 fim pelo CENDREV que consegue assim ir além da mera circunstância comemorativa, encontrando a chave para a leitura de um texto lúcido e sombrio na sua enigmática e profunda beleza teatral. 